\title{
Eelgrass survival in two contrasting systems: role of turbidity and summer water temperatures
}

\author{
Kenneth A. Moore*, Erin C. Shields, David B. Parrish, Robert J. Orth \\ Virginia Institute of Marine Science, School of Marine Science, 1208 Greate Road, College of William and Mary, \\ Gloucester Point, Virginia 23062, USA
}

\begin{abstract}
Eelgrass Zostera marina L. distribution patterns in the mid-Atlantic region of the USA have shown complex changes, with recovery from losses in the 1930s varying between the coastal lagoons and Chesapeake Bay. Restoration efforts in the coastal bays of Virginia introduced $Z$. marina back to this system, and expansion since 2005 has averaged $66 \% \mathrm{yr}^{-1}$. In contrast, Chesapeake Bay has experienced $2 \%$ expansion and has undergone 2 significant die-off events, in 2005 and 2010. We used a temperature-dependent light model to show that from 2005 to 2010 during daylight periods in the summer, coastal bay beds received at least $100 \%$ of their light requirements $24 \%$ of the time, while beds in the lower Chesapeake Bay only met this $6 \%$ of the time. Summer light attenuation $\left(K_{\mathrm{d}}\right)$ and temperatures from continuous monitoring at 2 additional Chesapeake Bay sites in 2010 suggest that the greater tidal range and proximity of the coastal bays to cooler ocean waters may ameliorate influences of exposure to stressful high water temperature conditions compared to Chesapeake Bay. A temperature difference of $1^{\circ} \mathrm{C}$ combined with a $K_{\mathrm{d}}$ difference of $0.5 \mathrm{~m}^{-1}$ at $1 \mathrm{~m}$ depth results in a $30 \%$ difference in available light as a proportion of community light requirements. These differences are critical between survival and decline in these perennial populations growing near the southern limits of their range. Without an increase in available light, Chesapeake Bay populations may be severely reduced or eliminated, while coastal bay populations, because of their proximity to cooler Atlantic waters, may become the refuge populations for this region.
\end{abstract}

KEY WORDS: Chesapeake Bay - Coastal ecosystem - Water quality - Turbidity - Seagrass ecosystems $\cdot$ Zostera marina $\cdot$ Restoration $\cdot$ Climate variation $\cdot$ Western mid-Atlantic

\section{INTRODUCTION}

Seagrass populations in estuarine and coastal bay systems have been declining globally (Green \& Short 2003, Orth et al. 2006a, Waycott et al. 2009), with nearly $25 \%$ of all seagrass species considered threatened or near threatened (Short et al. 2011). While numerous factors have been cited for these losses, reduced water quality and more specifically, reduced light availability related directly or indirectly to anthropogenic inputs of nutrients and sediments, have been documented as principal factors (Orth et al. 2006a, Waycott et al. 2009). Recently, warming sea surface temperatures have been sug- gested as another major factor that could have serious deleterious effects on seagrasses, especially at their range limits (Short \& Neckles 1999, Short et al. 2011). In the western mid-Atlantic coastal region, eelgrass Zostera marina grows near the southern limits of its range (Green \& Short 2003, Moore \& Short 2006), so the potential for increased water temperatures to become a major stressor is high, not only as regards the direct effects of high temperature on the eelgrass, but also as regards the potential interactions of high temperatures with other stressors (Koch \& Erskine 2001).

Light requirements for Zostera marina have been shown to increase with temperature (Wetzel \& Pen- 
hale 1983, Murray \& Wetzel 1987, Moore et al. 1997, Moore 2004), and photosynthetic capacities decrease at high summertime temperatures (Evans et al. 1986, Zimmerman et al. 1989), thereby decreasing growth and production (Zharova et al. 2001, Pastres et al. 2004). Increases in water temperatures can also increase sediment and water column community respiration, potentially resulting in increased periods of hypoxia or anoxia (Moore 2004, Greve et al. 2005). Temperature can have a substantial influence on meristematic oxygen balance (Borum et al. 2006), with plant respiration increasing more with increasing temperatures than photosynthesis (Evans et al. 1986). Greater diffusion and loss of oxygen from eelgrass roots into the sediments due to increasing temperature-dependent, microbial respiration rates can further stress the plants (Holmer \& Bondgaard 2001). Staehr \& Borum (2011) found that while there can be seasonal acclimation of $Z$. marina to temperature, in their laboratory-based experiments, respiration increased significantly more than photosynthesis especially at temperatures above $20^{\circ} \mathrm{C}$, and they concluded that:

high temperatures may have more severe negative effects on seagrass survival than just from reducing the carbon balance of the plants. (p. 145)

Periods of sediment hypoxia have been associated with declines of seagrasses in several areas (Robblee et al. 1991, Carlson et al. 1994, Koch et al. 2007). Greve et al. (2003) found that oxygen supply to Zostera marina tissues is highly variable and is dependent on plant photosynthesis, water column and sediment oxygen concentrations, and $Z$. marina community oxygen consumption rates. Toxic metabolites such as ethanol and lactate can accumulate within plant tissues under anoxic conditions (Crawford \& Braendle 1996, Vartapetian \& Jackson 1997). Additionally, sulfide, which is strongly phytotoxic (Koch \& Erskine 2001), can diffuse from the sediments into plant tissues under low oxygen conditions (Frederiksen et al. 2006), reducing photosynthesis and growth (Goodman et al. 1995, Erskine \& Koch 2000, Holmer \& Bondgaard 2001, Borum et al. 2005, 2006), which can result in significant losses of vegetation (Carlson et al. 1994). Laboratory studies of $Z$. marina found it very sensitive to short-term periods of exposure to anoxic seawater, with significantly reduced photosynthesis and growth at increased temperature (Pulido \& Borum 2010).

The effects of short-term stress have been shown to have long-term effects on eelgrass persistence. Moore et al. (1997) found that short-term periods of high turbidity for as little as $20 \mathrm{~d}$ resulted in a die-off of Zostera marina transplants in Chesapeake Bay (USA), in contrast to transplant growth and survival in a comparable area which did not receive the turbidity stress. Periods of high summertime water temperatures were found to be related to diebacks of $Z$. marina in Danish waters (Greve et al. 2005). In the summer of 2005, a die-off of $Z$. marina in Chesapeake Bay was associated with low water column dissolved oxygen concentrations of 1 to $3 \mathrm{mg} \mathrm{l}^{-1}$ which occurred only 3 to $5 \%$ of the time in July and August of that year, as well as a higher proportion of time when water temperatures exceeded $29^{\circ} \mathrm{C}$ during the same period (Moore \& Jarvis 2008).

The lower Chesapeake Bay and nearby eastern shore coastal lagoons have historically supported extensive Zostera marina populations (Orth \& Moore 1984, Orth et al. 2006b, 2010a, Koch \& Orth 2003). However, in the 1930s, impacts from the 'wasting disease' caused by a virulent strain of the pathogenic slime mold Labyrinthula zosterae devastated populations in these regions (Rasmussen 1977). Recovery from this event was not quantified, but $Z$. marina did eventually return to the higher-salinity regions of Chesapeake Bay (Orth \& Moore 1984), while recovery in the more isolated eastern shore lagoons was limited, due possibly to limited propagule availability (Orth et al. 2012, this Theme Section).

More recently, Zostera marina populations in Chesapeake Bay have shown a pattern of decline, reaching current levels which are $65 \%$ of those observed only several decades ago (Orth et al. 2010a; Fig. 1, inset). A wide range of restoration efforts attempted during that period have had only limited success (Orth et al. 2010a). In contrast, Z. marina populations in the Virginia coastal lagoons, which were started by seeds initially collected from Chesapeake Bay populations (Orth et al. 2012), have shown dramatic increases since populations were first established from seeds in 1997. While reduced light availability has been the primary factor affecting Z. marina success throughout Chesapeake Bay (Moore et al. 1996, 1997, Kemp et al. 2004, Orth et al. 2010b), it has not been a factor limiting $Z$. marina growth and abundance in the coastal bays (Lawson et al. 2007, McGlathery et al. 2012, this Theme Section, Orth et al. 2012). While summertime die-offs associated with high temperatures were occurring in Chesapeake Bay in 2005 (Moore \& Jarvis 2008), $Z$. marina in the Virginia coastal bays expanded (Orth et al. 2012), apparently unaffected by the stressful conditions occurring in the neighboring Chesapeake system. 
The persistence and spread of Zostera marina in these coastal bays, unlike Chesapeake Bay populations, suggests some ameliorating effects of the environment in the coastal bays during summertime periods associated with diebacks in Chesapeake Bay. The objectives of this paper were therefore to assess both the levels and variability in the water quality conditions associated with the successful growth of $Z$. marina in the coastal bays system, and compare these to conditions in declining $Z$. marina areas in the lower Chesapeake Bay, to determine what factors and levels of these factors may be influencing these divergent population responses.

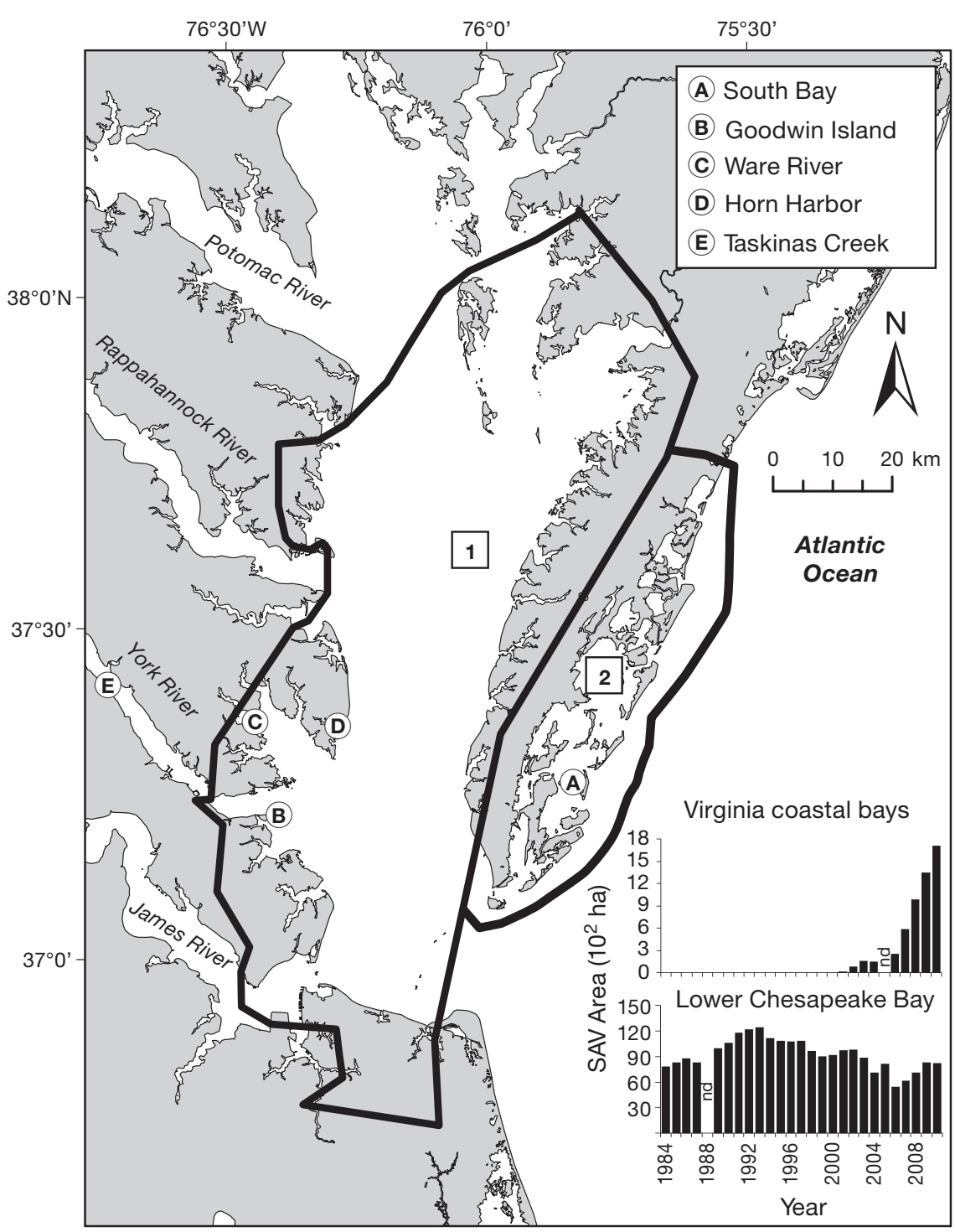

Fig. 1. Zostera marina. Occurrence region in the lower Chesapeake Bay (1) and the Virginia coastal bays region (2), USA. A-D are water quality monitoring sites; E is the meteorological monitoring site. Inset histograms show bed areas (in $10^{2}$ ha) of submerged aquatic vegetation (SAV) monitored annually over time. nd: not determined. Figure modified from Orth et al. (2010a)

\section{MATERIALS AND METHODS}

\section{Study sites}

Four study sites with existing Zostera marina beds were studied for water quality conditions and Z. marina persistence (Fig. 1). One site, South Bay, is located within a large $Z$. marina restoration site in 1 sub-basin along the Virginia and Maryland (USA) Delmarva peninsula's coastal bay system (see Orth et al. 2012). South Bay is part of the Virginia Coast Reserve LongTerm Ecological Research site. Three other sites (Goodwin Island, Ware River, and Horn Harbor) are located along the western littoral zone of the lower Chesapeake Bay in or near areas vegetated by $Z$. marina. All 4 study sites are of comparable depths (0.5 to $1.0 \mathrm{~m}$ mean sea level).

\section{Water quality}

Water quality measurements were made at each of the study sites using YSI 6600 EDS V2 multi-parameter sondes which were fixed to pilings and located between 0.25 and $0.51 \mathrm{~m}$ above the bottom at each site. The South Bay station was deployed from 2005 through 2010. Four 2 to $3 \mathrm{wk}$ deployments were conducted each year between 2006 and 2009, while in 2005, only three 2 wk deployments were conducted during the study period. In 2009, a sonde was deployed continuously from 28 July through 18 December, and in 2010 continuously from 8 March through 31 December. A sonde at the Goodwin Island, Chesapeake Bay station, which is part of the Chesapeake Bay $\mathrm{Na}_{\text {. }}$ tional Estuarine Research Reserve in Virginia (CBNERRVA) monitoring network, was deployed continuously from 2005 to 2010. The 2 other Chesapeake Bay stations, Horn Harbor and Ware River, had sondes deployed from 1 April to 30 November 2010. Water quality was measured at 15 min intervals throughout each deployment. Measurements included turbidity (in NTU), chlorophyll fluorescence, temperature, salinity, $\mathrm{pH}$, 
dissolved oxygen, and depth. Sondes were replaced at 1 to 3 wk intervals, depending on fouling rates, with newly calibrated instruments. All sensors on the YSI 6600 EDS sondes were both calibrated predeployment and checked post-deployment according to YSI standard procedures. Diffuse downwelling attenuation of photosynthetically available radiation (PAR) was determined using triplicate water column measurements of downwelling photosynthetic photon flux density measured with a LI-192SA underwater quantum sensor (LI-COR) taken every $25 \mathrm{~cm}$ from $10 \mathrm{~cm}$ below the surface to $25 \mathrm{~cm}$ above the bottom. YSI turbidity measurements were modeled to light attenuation by least squares regression relating turbidity to downwelling light attenuation coefficients $\left(K_{\mathrm{d}}\right)$ using the simultaneously measured light profiles and turbidities taken throughout the course of the studies. Bio-optical models of light attenuation within similar seagrass habitats in coastal estuarine and bay systems (Gallegos 1994, 2001, Biber et al. 2008) have shown that turbidity, chlorophyll, and colored dissolved organic matter (CDOM) can form variable optical components of the water. In the coastal bay and lower estuarine areas studied here, both chlorophyll and CDOM have little effect on light attenuation coefficients, while total suspended solids dominated (Cerco \& Moore 2001, Lawson et al. 2007). Downwelling insolation measurements of PAR were continuously recorded at 15 min intervals at Taskinas Creek (Fig. 1) using a LI-190SA terrestrial quantum sensor (LI-COR) from 2005 to 2010.

\section{Aerial imagery}

Zostera marina bed areas for both the Chesapeake Bay and South Bay regions were derived from 1:24 000 scale aerial photography acquired annually during the May to July period of highest abundance of $Z$. marina in this mid-Atlantic region (Moore et al. 2000). Details for the acquisition, photo-interpretation and processing of the seagrass signatures, and $Z$. marina abundance data are provided by Moore et al. (2009) and Orth et al. (2010b, 2012). Ground surveys were conducted each year to confirm the occurrence of $Z$. marina in these areas.

\section{Compensating light $\left(I_{c}\right)$ and light to the bottom $\left(I_{z}\right)$ calculations}

Zostera marina community compensating light requirement $\left(I_{\mathrm{C}}\right)$ at each of the study sites was deter- mined using a linear least squares regression model developed for this mid-Atlantic area (Wetzel \& Penhale 1983, Moore et al. 1997) that relates in situ measures of $Z$. marina community light compensation to water temperature $\left(\log \left(I_{\mathrm{c}}\right)=0.057 \times\right.$ temp $+1.01 ; \mathrm{r}^{2}=$ 0.99). Water temperatures were recorded every 15 min using the YSI sondes at each site.

To better understand the water quality trends over the tidal cycles at each station relative to tidal influences, the water depth values that were determined every $15 \mathrm{~min}$ by the non-vented YSI sonde at each location were corrected from the barometric pressure set at calibration prior to deployment to the actual barometric pressures at sampling times. This was done using 15 min interval barometric measurements from the Taskinas Creek meteorological station (Fig. 1). The fixed distance of each moored sonde above the bottom was then added to each of the 15 min corrected depth values to get the actual water depths at each site. The long-term average water level relative to the bottom of these water depths was determined using all available depth data from each site, and the differences between the long-term mean for South Bay and the long-term means for each of the other stations were calculated. To normalize the 3 Chesapeake Bay sites relative to the South Bay site for light to the bottom $\left(I_{z}\right)$ calculations, each depth value at each station was then adjusted to this consistent average water level reference.

The percent light through water to the bottom (PLW) was calculated using Eq. (1), where $K_{\mathrm{d}}$ is modeled from the 15 min turbidity values and $z$ is the 15 min depth values taken at each site and normalized to a common sea level datum:

$$
\mathrm{PLW}=100 \times \mathrm{e}^{\left(K_{\mathrm{d}} \times z\right)}
$$

PLW was then used to calculate the light to the bottom $\left(I_{z}\right)$ using Eq. (2), where PAR was the $15 \mathrm{~min}$ reading taken from the Taskinas Creek meteorological station:

$$
I_{z}=(\mathrm{PAR} \times \mathrm{PLW}) / 100
$$

\section{Statistical analyses}

Continuous water quality measurements made at the fixed monitoring stations at South Bay, Goodwin Island, Ware River, and Horn Harbor during the June to August 2010 deployment periods were compared among sites using Kruskal-Wallis rank sum tests. Paired post hoc comparisons followed procedures originally published in Siegel \& Castellan (1988). Regression analysis was used to develop sep- 
arate conversions between fixed station turbidity measurements and underwater light attenuation coefficients for the South Bay station and the combined Chesapeake Bay stations, as the optical properties of the water can differ between the coastal and estuarine regions due to varying dissolved and particulate components in the water column (Gallegos et al. 1990, Gallegos 2005, Biber et al. 2008). Comparison of long-term mean frequency distributions of water temperatures, dissolved oxygen, light attenuation coefficients, and proportion of light requirements met by light availability were accomplished using Kolmogorov-Smirnov tests for significance (StatView).

\section{RESULTS}

Zostera marina abundance in the Virginia coastal bays increased gradually during the early phases of the restoration efforts (Orth et al. 2012) through 2006, when 253 ha were recorded, and then more rapidly through 2010 when 1715 ha were reported (Fig. 1). $Z$. marina abundance in Chesapeake Bay declined from 1993 through 2006. There was a significant dieback observed in Chesapeake Bay between the aerial mapping surveys in 2005 and 2006 (Fig. 1) which occurred at the end of the summer of 2005 (Moore \& Jarvis 2008, Jarvis \& Moore 2010, Orth et al. 2010b). Since then there has been only a modest increase with little change between the 2009 and 2010 surveys, which for 2010 was $34 \%$ less than the eelgrass abundance reported in 1993. Field observations at the end of August 2010 (R. J. Orth pers. obs.) revealed widespread diebacks of the $Z$. marina beds throughout the lower Chesapeake Bay, in contrast to little dieback evident at the South Bay restoration area.

Goodwin Island had a proportionally higher duration of water temperatures $27^{\circ} \mathrm{C}$ and above, with the cumulative distribution of higher temperatures at Goodwin Island exceeding that of South Bay from June through August for the period of 2005 to 2010 ( $p<0.01$, Fig. 2). Light-turbidity models developed separately for the coastal bay and Chesapeake Bay stations resulted in a good fit between the 2 different measurements of water clarity: South Bay $K_{\mathrm{d}}=0.0885$ (Turbidity) $+0.5529, \mathrm{r}^{2}=0.716$; Chesapeake Bay $K_{\mathrm{d}}=$ 0.0869 (Turbidity) $+1.1976, \mathrm{r}^{2}=0.771$. Higher $(\mathrm{p}<0.01)$ levels of light attenuation were observed at Goodwin Island, with the distribution shifted approximately $0.5 \mathrm{~m}^{-1}$ higher at that site compared to the South Bay site. The resultant distributions of percentage light available to light required $\left(I_{z} / I_{\mathrm{C}}\right)$ for Goodwin Island and South Bay (Fig. 3) showed that it was significantly lower $(\mathrm{p}<0.01)$ at the Chesapeake Bay site. This was related to both the warmer water temperatures, which increased light demand $\left(I_{\mathrm{c}}\right)$, and the more turbid conditions, which reduced the light availability $\left(I_{z}\right)$.

Water-column dissolved oxygen concentrations measured at or just above the Zostera marina canopy rarely fell below $4 \mathrm{mg} \mathrm{l}^{-1}$ during the summer periods of 2005 to 2010 at either Goodwin Island or South Bay. For example, during the summer of 2010, dissolved oxygen levels of 2 to $4 \mathrm{mg} \mathrm{l}^{-1}$ occurred only 6 times at South Bay and 6 times at Goodwin Island for an average duration of 7.5 and $7.8 \mathrm{~h}$, respectively, during these events. Overall, the measured dissolved oxygen levels were slightly, but significantly $(p<$ 0.01), higher at Goodwin Island than at South Bay (Fig. 2).

Comparisons of $1 \mathrm{~d}$ means of water temperatures and light attenuation for the South Bay site and the 3 Chesapeake Bay sites for the period of May through September 2010 (Fig. 4) revealed that in spite of considerable variability in daily temperatures and turbidities, the South Bay site was consistently cooler and less turbid (lower light attenuation) than the Chesapeake Bay areas (Fig. 5). Overall, water temperature differences between South Bay and the Chesapeake Bay sites were larger during the periods of June through August when water temperatures were at their seasonally highest levels. Additionally, short periods of a few days to a week could be observed when water temperature differences were much greater between the coastal lagoon Zostera marina bed and the Chesapeake Bay beds. Light attenuation also showed considerable temporal variability, with very high levels usually associated with storms or other high wind events. For example, short-term spikes in light attenuation observed in May and September 2010 (Fig. 4) corresponded to average winds from the north of $11.7 \mathrm{~m} \mathrm{~s}^{-1}$, with average gusts of $14.1 \mathrm{~m} \mathrm{~s}^{-1}$ on 8 to 9 May, and north winds of $11.9 \mathrm{~m}$ $\mathrm{s}^{-1}$, with average gusts of $15.0 \mathrm{~m} \mathrm{~s}^{-1}$ on 3 September (NOAA National Ocean Service Station KPTV2 Kiptopeke, VA, $37.167^{\circ} \mathrm{N}, 75.988^{\circ} \mathrm{W}$ ). In comparison, average wind speeds from May through September 2010 were $4.4 \mathrm{~m} \mathrm{~s}^{-1}$ with variable direction.

Median water quality conditions for the 2010 June through August period (Fig. 5) showed significantly $(p<0.05)$ higher water temperatures comparing the Chesapeake Bay sites and the South Bay coastal bay restoration area, with the Goodwin Island Zostera marina bed lying intermediate between the other 2 Chesapeake Bay sites and South Bay. Similarly, median light attenuation was significantly lower at 

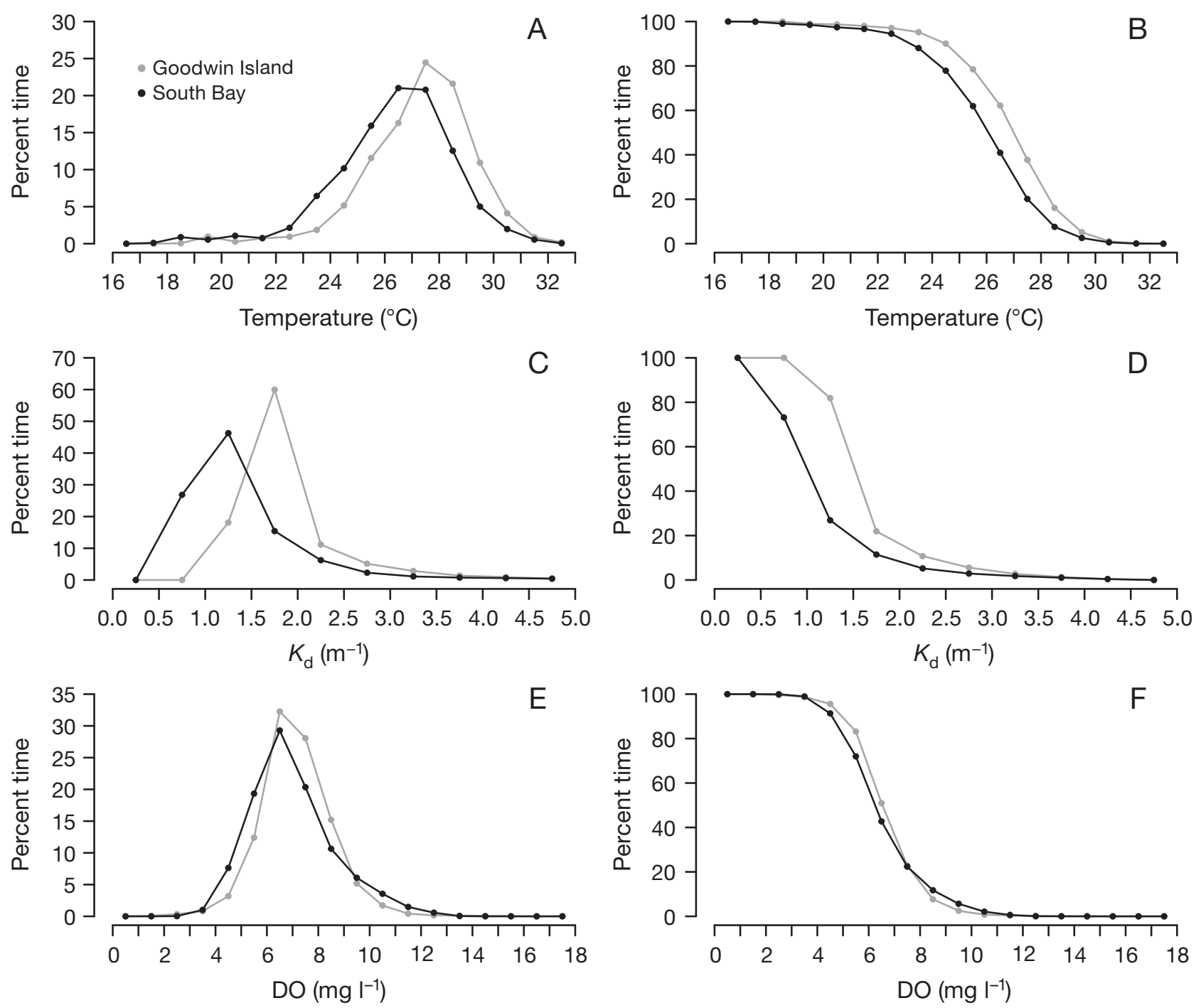

Fig. 2. (A,,$E$, E) Frequency distributions and (B,D,F) cumulative frequency distributions for June through August 2005 to 2010 water temperatures, light attenuation $\left(K_{\mathrm{d}}\right)$, and dissolved oxygen (DO) at Goodwin Island and South Bay. Graphs present mean binned frequencies of all data for each parameter and site. In $(A, C, E)$, note differences in $y$-axis scales

South Bay than the other areas. The resultant determinations of percentage light available relative to compensating light requirements $\left(I_{z} / I_{\mathrm{c}}\right)$ revealed a significantly higher proportion of light requirements met at South Bay compared to the Chesapeake Bay sites, with the lowest level of light requirements met at Horn Harbor due to its highest levels of water temperatures and light attenuation.

Analysis of temperature and turbidity records for the period of June through August 2010 relative to tidal periods revealed marked differences among the sites (Fig. 6). First, the overall tidal range was greater at South Bay compared to the Chesapeake Bay sites where the average tidal range of South
Bay was $1.18 \mathrm{~m}$, as compared to $0.64 \mathrm{~m}$ at Goodwin Island, $0.50 \mathrm{~m}$ at Horn Harbor, and $0.71 \mathrm{~m}$ at Ware River. At low tidal levels, water temperatures were more similar at South Bay to those at the 3 Chesapeake Bay sites. At high tides, the water temperatures were reduced by nearly $2^{\circ} \mathrm{C}$ compared to low tide, while high tides at the Chesapeake Bay sites resulted, on average, in only $0.5^{\circ} \mathrm{C}$ or less reduction in water temperatures. Light attenuation showed evidence of higher attenuation levels at lower tidal periods at the 3 Chesapeake Bay sites, while at South Bay there was evidence that higher turbidities were associated with the initial flooding periods after low tides. 


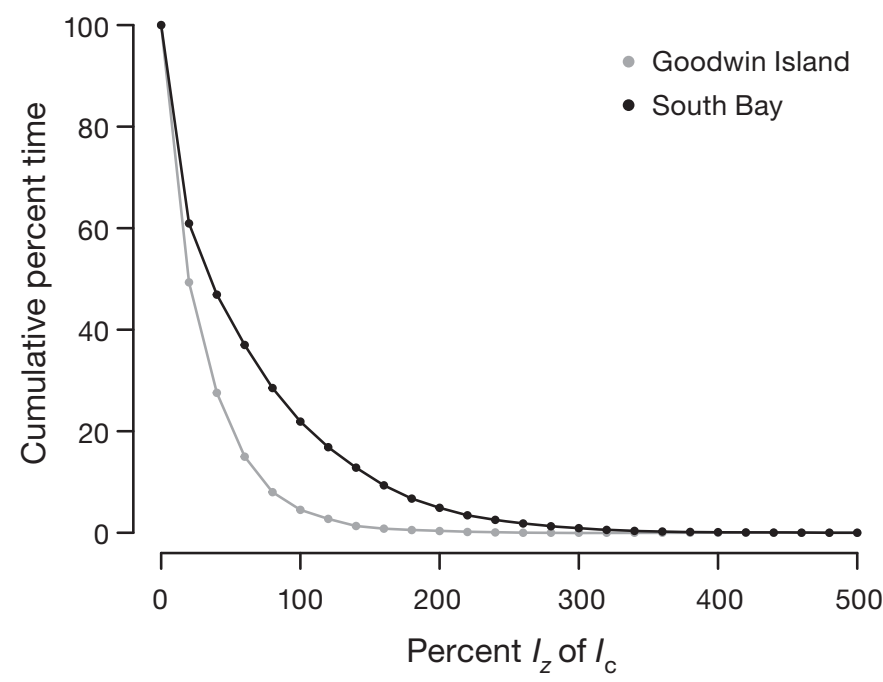

Fig. 3. Cumulative frequency distribution of percent light available (light to the bottom, $I_{z}$ ) of compensating light requirement $\left(I_{\mathrm{C}}\right)$ at Goodwin Island and South Bay for June through August 2005 to 2010. Graphs present mean binned frequencies of all data for each site

\section{DISCUSSION}

Results of this study indicate that a combination of factors, including lower summertime water temperatures and lower light attenuation, interact to both increase the proportion of light available for Zostera marina photosynthesis and decrease the $Z$. marina community light requirements at the South Bay restoration site compared to sites in the lower Chesapeake Bay. This results in markedly improved conditions for $Z$. marina growth and meadow expansion in South Bay compared to the lower Chesapeake Bay. Since 2005, seed-based $Z$. marina restoration efforts in the Virginia Coastal Bay region have resulted in bed expansion at a rate of $66 \% \mathrm{yr}^{-1}$. In contrast, the lower Chesapeake Bay Z. marina beds have only shown an expansion rate of $2 \% \mathrm{yr}^{-1}$ following a significant die-off event by the end of the summer of 2005 (Moore \& Jarvis 2008). The application of the temperature-dependent compensating light model demonstrates that during the summers from 2005 to
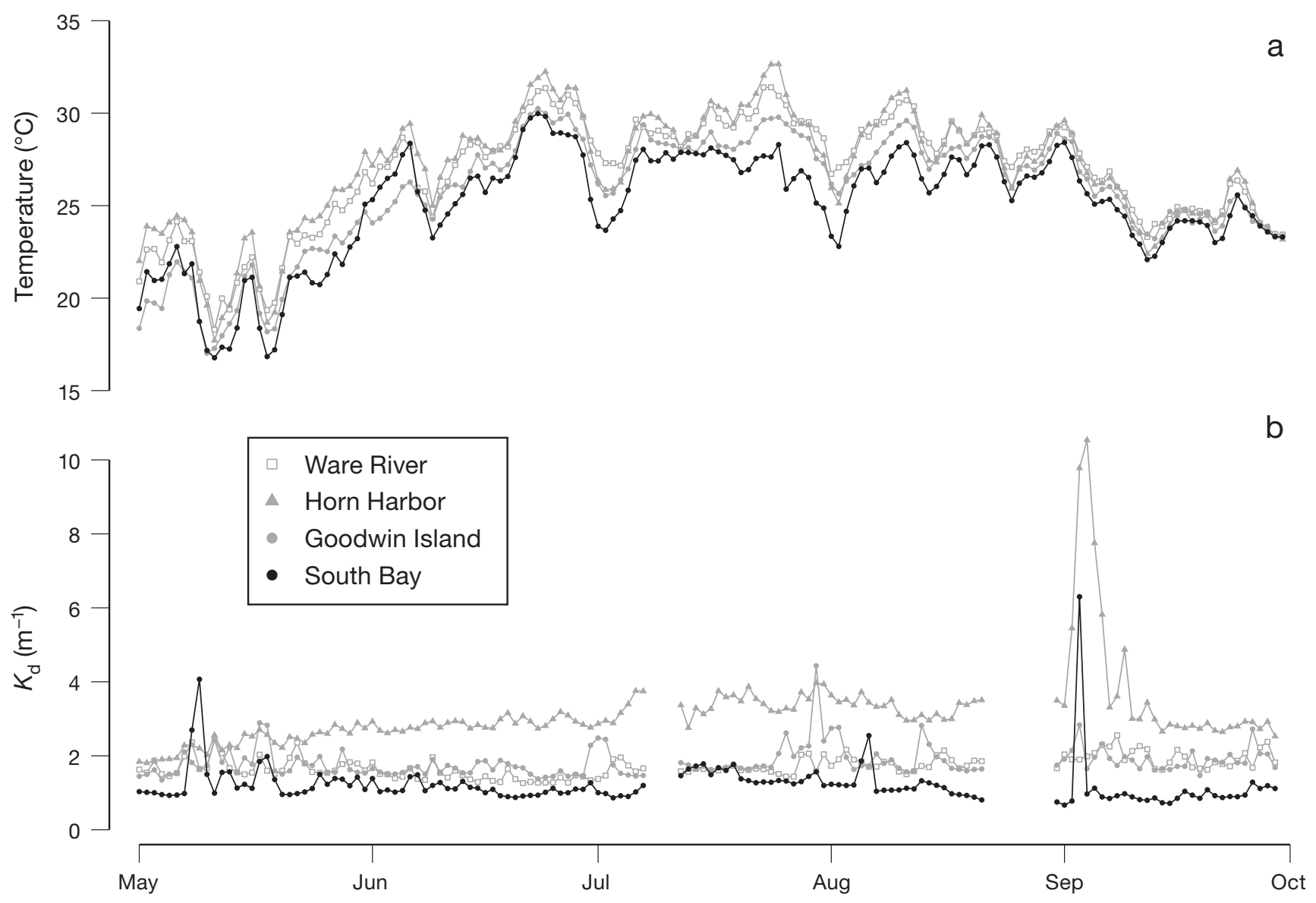

Fig. 4. May to October 2010 (a) daily mean water temperatures and (b) light attenuation (K $K_{\mathrm{d}}$ ) for Ware River, Horn Harbor, Goodwin Island, and South Bay 

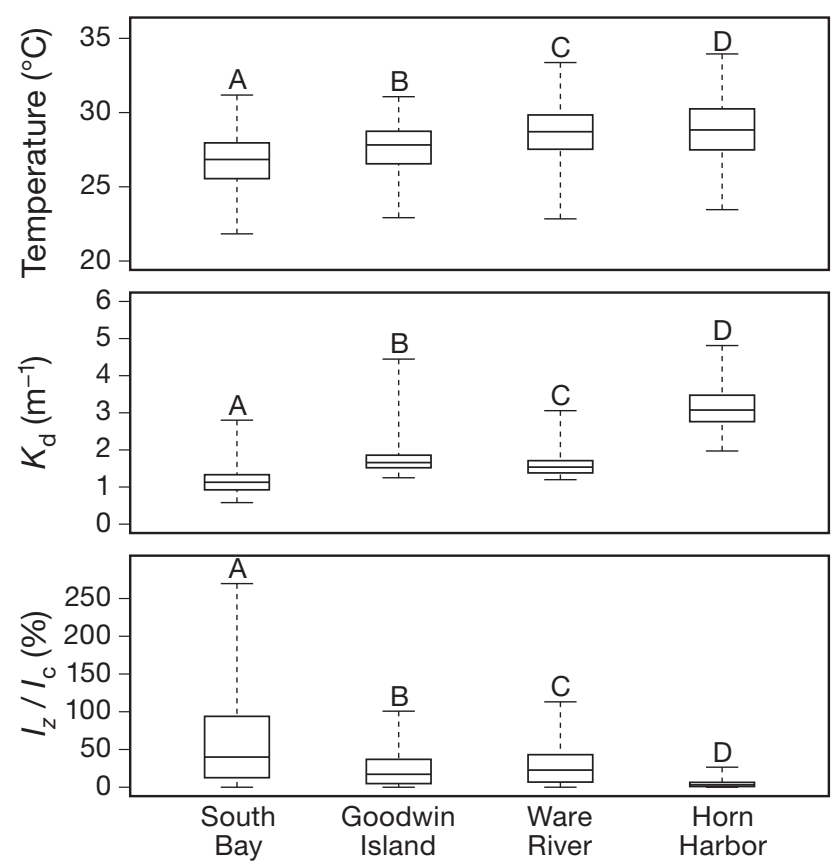

Fig. 5. Water temperature, light attenuation $\left(K_{\mathrm{d}}\right)$, and percent light available (light to the bottom, $I_{z}$ ) of compensating light requirement $\left(I_{\mathrm{c}}\right)$ for South Bay, Goodwin Island, Ware River, and Horn Harbor for June through August 2010, showing median, 25th and 75th percentiles, and the minimum and maximum of the lower $99 \%$ of the data. Data are 15 min records. Identical letters indicate no significant differences $(p>0.05)$ in median values between the sites
2010, the South Bay beds received at least $100 \%$ of their community-compensating light requirements $24 \%$ of the time during the day, while populations in the Goodwin Island region of the lower Chesapeake Bay received compensating light only $6 \%$ of the time. In the summer of 2010, the addition of 2 other Z. marina monitoring sites in the lower Chesapeake Bay confirmed this trend, with median light levels as a proportion of light requirements significantly higher at South Bay $(40 \%)$ compared to Goodwin Island (16\%), Ware River $(21 \%)$, and Horn Harbor $(3 \%)$ in Chesapeake Bay.

Reductions in attainment of compensating light levels are related to reductions in the distribution and abundance of Zostera marina, as well as other seagrass species in coastal areas (Dennison \& Alberte 1982, 1985, Zimmerman et al. 1994, Lee et al. 2007). Our work adds to the results of these studies and suggests that relatively modest changes near the upper tolerance limits in water temperature and clarity can result in pronounced differences in the trajectories of Z. marina population expansion or contraction. Analyses here suggest that a summertime temperature difference of $1^{\circ} \mathrm{C}$, combined with a $K_{\mathrm{d}}$ difference of $0.5 \mathrm{~m}^{-1}$, would result in a $30 \%$ difference in available light at $1 \mathrm{~m}$ depths as a proportion of the $Z$. marina community light requirements. This difference may represent a threshold between expansion and die-
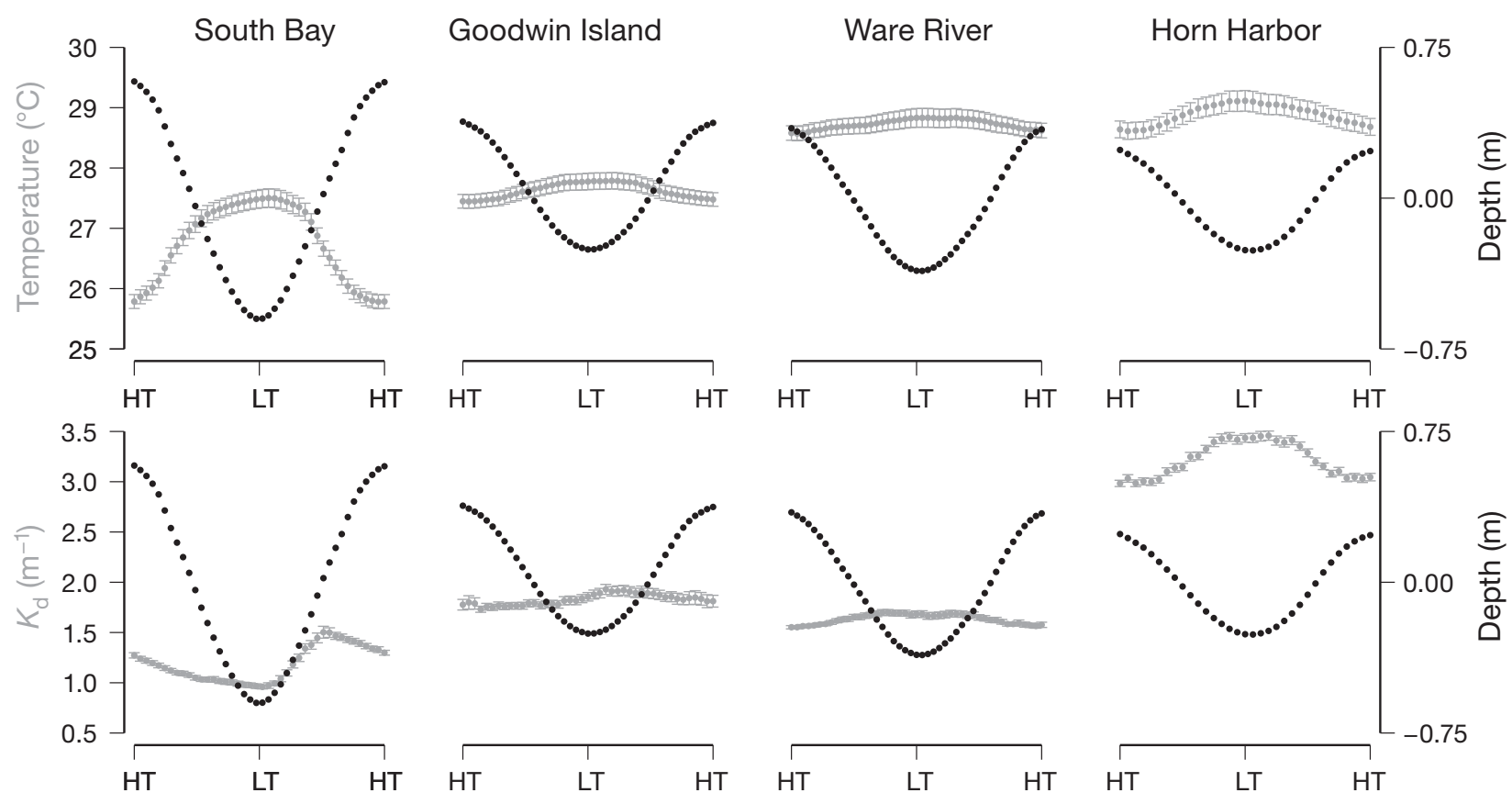

Fig. 6. Aggregated tidal periodicity in water temperatures (mean $\pm \mathrm{SE}$ ), light attenuation $\left(K_{\mathrm{d}}\right.$ mean $\left.\pm \mathrm{SE}\right)$, and water depths (mean, relative to mean sea level) for June through August 2010. HT: high tide, LT: low tide 
back of $Z$. marina beds growing in this region of the mid-Atlantic, which is near the southern limit of its range along this coast (Koch \& Orth 2003).

In addition to climate and latitudinal effects on temperature, site-specific factors such as tides can play an important role in the balance between Zostera marina habitat suitability and sustainability. Analyzing summer light attenuation and temperatures from continuously recording datasondes at 4 stations in 2010 suggests that the greater tidal range and proximity of the coastal bays to cooler ocean waters may be an ameliorating influence on the duration of exposure to stressful conditions. The significant decreases in water temperatures at high tide, on average, compared to low tide is likely to be very important in reducing the overall light requirements of the $Z$. marina community. In comparing South Bay to Goodwin Island (Fig. 6), while maximum summertime water temperatures during low tidal periods were very similar, water temperatures at South Bay were below those of Goodwin Island for approximately $50 \%$ of each day. During 2 to $3 \mathrm{~h}$ at high tide, the difference was on average nearly $2^{\circ} \mathrm{C}$. Monitoring data at the other Chesapeake Bay sites show similar patterns of very limited change in water temperatures with tidal phase, suggesting that the surface water masses in the vicinity of each station were relatively consistent in temperature. In contrast, the warming and cooling cycles observed at the South Bay site suggest that water masses of differing temperatures influenced the $Z$. marina beds there. The summer water temperatures at the Ware River and Horn Harbor sites were significantly higher than at the Goodwin Island site (Fig. 5). As these sites are located in more embayed areas than Goodwin Island, it suggests that the physical location of the $Z$. marina beds along the shore can also be a factor affecting temperature stress.

Water clarity levels were also observed to vary markedly with tidal phase (Fig. 6). At South Bay, the rapid increase in turbidity with flooding tide suggests that in addition to wind- and storm-generated resuspension (Koch et al. 2006, Chen et al. 2007, Lawson et al. 2007), tidal energies were sufficient at the site to re-suspend sediments and reduce water clarity. Much less effect was seen at all 3 Chesapeake Bay sites. Although tidal currents were not measured here, the much larger tidal range and broader shallow flats at South Bay compared to the Chesapeake Bay sites may result in higher tidal currents during the early flood. All 3 Chesapeake Bay sites showed, on average, slightly to markedly lower water clarity, around low tide versus high tide compared to the
South Bay site. This may reflect the relatively greater effect of wind waves on the shallow water bottoms at low tidal levels in these areas. Moore (2004) reported that the effect of Zostera marina bed structure was not evident until seagrass cover reaches 25 to $50 \%$. The relatively dense $Z$. marina beds at South Bay (Orth et al. 2012), compared to the much more sparse and less expansive beds at the Chesapeake Bay sites (Orth et al. 2010b), may influence the beds' capacities to attenuate re-suspension, especially during lower tides (Hansen \& Reidenbach 2012, this Theme Section).

Orth et al. (2012) observed that the water clarity in South Bay has improved significantly since 2003 as the Zostera marina vegetated areas have increased. This suggests that water clarity conditions at South Bay were better in 2010 than in the recent past. However, in comparison to the Goodwin Island site monitored here since 2005, water clarity in South Bay was at least as good or better over this entire time period. The additional positive effects of cooler water temperatures on $Z$. marina persistence at South Bay support the results of transplant studies in both Chesapeake and South Bay sites over this time period (Orth et al. 2010a), which conclude that conditions have been more suitable for $Z$. marina restoration in South Bay compared to Chesapeake Bay.

Water temperatures in 2010 at the Chesapeake Bay and South Bay sites all demonstrated similar seasonal trends, as well as short-term variability over days to weeks (Fig. 4). These are likely reflective of variation in air temperatures over the summer. However, differences in water temperatures between the coastal South Bay site and the Chesapeake Bay sites were not consistent, and differences ranged from $<1^{\circ} \mathrm{C}$ to $>5^{\circ} \mathrm{C}$ (Fig. 4). This suggests varying influence of offshore waters on the coastal bay, which might be related to short-duration upwelling events or other factors affecting nearshore water conditions in this region (Clemente-Colon \& Yan 1999, Austin 2002). The effect of this variability could be significant. For example, very hot periods during the summer, especially during weeks when low tides are occurring around mid-day, can result in very elevated water temperatures in the nearshore, shallow vegetated areas. This has been observed to cause significant diebacks of Zostera marina in Chesapeake Bay, even if the events only occur for a few days to a week (Orth \& Moore 1986). However, alongshore southern winds, which are relatively normal during these periods (Clemente-Colon \& Yan 1999), can produce offshore surface Ekman flows that regularly bring colder water to the surface (Glenn et al. 1996) and 
potentially into the coastal bays, thus buffering the $Z$. marina there from the pulses of high temperatures.

The effect of high temperatures of short duration on Zostera marina in Chesapeake Bay was observed in 2005 when there was a nearly complete dieback of aboveground vegetation by the end of August following a period of unusually high water temperatures (Moore \& Jarvis 2008). This dieback phenomenon was not observed in the coastal bays (Orth et al. $2010 \mathrm{a}, \mathrm{c})$. This difference was recorded in 2006 when overall abundance of aerial mapping of $Z$. marina in Chesapeake Bay declined, while populations in the coastal bays continued to increase (Fig. 1). Similarly, in June 2010, air temperatures were observed to be unusually high for several weeks (data not shown), with concurrent increases in shallow water temperatures (Fig. 4). As in 2005, a general dieback in Z. marina in Chesapeake Bay was observed subsequent to this but again, not in the coastal bays (R. J. Orth \& E. C. Shields pers. obs.). Z. marina can become stressed at $25^{\circ} \mathrm{C}$ (Rasmussen 1977), and an upper limit range from 28 to $30^{\circ} \mathrm{C}$ has been proposed as a critical threshold for growth (Evans et al. 1986, Orth \& Moore 1986, Abe et al. 2008). Temperatures exceeding $30^{\circ} \mathrm{C}$ for prolonged periods have been associated with large-scale declines and transplant failures in the Chesapeake Bay (Moore \& Jarvis 2008, Golden et al. 2010, Jarvis \& Moore 2010, Tanner et al. 2010) as well as in laboratory studies (Pulido \& Borum 2010, Staehr \& Borum 2011). While daily mean temperatures were not consistently above $30^{\circ} \mathrm{C}$ over the entire 2010 summer, there were varying periods in late June and July in which plants were exposed to these stressful temperatures. The apparent connection between high temperatures and dieback, at different periods during the summer, suggests that temperature stress, even at varied periods during the summer, can have long-term effects on plant persistence (Staehr \& Borum 2011). Burke et al. (1996) showed that having adequate carbon reserves is very important for $Z$. marina persistence through the summer. Various stresses can reduce carbon reserves such that summertime survival can be compromised even if conditions return to more normal patterns. Given the persistently higher summertime temperatures for Chesapeake Bay populations combined with generally higher turbidities, pulsed stresses, even for short durations, can have long-lasting effects.

Low water-column oxygen concentrations can have a compounding effect on temperature and light stresses (Greve et al. 2003, Borum et al. 2005, 2006). Pulido \& Borum (2010) demonstrated that short-term exposure $(<24 \mathrm{~h})$ to water significantly reduce
Zostera marina photosynthetic performance and growth and can increase mortality, and that these effects increase with temperature. At the sites studied here, measured water-column dissolved oxygen rarely dropped below $4 \mathrm{mg} \mathrm{l}^{-1}$ and never became anoxic, even during the highest temperature periods in the summer. These observations are similar to those observed previously by Moore (2004) for the Goodwin Island $Z$. marina site. This suggests that while low water-column dissolved oxygen may be a continuing summertime stress to the $Z$. marina here, specific low dissolved oxygen events were likely not the precipitating factor causing the widespread dieoff in 2010. While water-column dissolved oxygen levels remained relatively high at the monitoring stations, it is certainly possible that in some other areas with low water movement and very high bacterial respiration due to high organic matter accumulations, water column anoxia, especially as it may affect meristematic tissues near the sediment surface, may result in plant mortality (Pulido \& Borum 2010). In fact, isolated diebacks which may be examples of this have been observed in other lower Chesapeake Bay Z. marina areas in the past (Orth \& Moore 1986).

The results of our study of these estuarine and coastal bay systems are important for 2 reasons. First, they provide critical data on key processes of growth and survival that have allowed Zostera marina to survive and spread in the coastal bays compared to Chesapeake Bay populations. Second, they are relevant in the debate surrounding the implications of climate change for plant and animal populations as this influences the overall temperature regime. These temperature scenarios suggest that without an increase in available light, Chesapeake Bay populations may be severely reduced or possibly eliminated, while coastal bay populations, because of their proximity to cooler Atlantic waters, may become the refuge populations for this region.

Acknowledgements. We gratefully acknowledge field and laboratory assistance by B. Neikirk, J. Goins, S. Snyder, V. Hogge, J. Austin, A. Miller, and A. Knowles. Funds for this project were provided by the Virginia Department of Environmental Quality, The Estuarine Research Reserve Division of the National Oceanic and Atmospheric Administration (NOAA), The Coastal Program of the Department of Environmental Quality funded by the Coastal Zone Management Act of 1972, as amended, and administered by NOAA's Office of Ocean and Coastal Resource Management, and the American Recovery and Reinvestment Act with funding from NOAA to the Nature Conservancy Grant No. NA09NMF4630308. This is contribution No. 3197 from the Virginia Institute of Marine Science, School of Marine Science, College of William and Mary. 


\section{LITERATURE CITED}

Abe M, Kurashima A, Maegawa M (2008) Temperature requirements for seed germination and seedling growth of Zostera marina from central Japan. Fish Sci 74:589-593

Austin HM (2002) Decadal oscillations and regime shifts, an empirical characterization of the Chesapeake Bay marine climate. Am Fish Soc Symp 32:155-170

Biber PD, Gallegos CL, Kenworthy WJ (2008) Calibration of a bio-optical model in the North River, North Carolina (Albermarle-Pamlico Sound): a tool to evaluate water quality impacts on seagrasses. Estuar Coasts 31:177-191

$>$ Borum J, Pedersen O, Greve TM, Frankovich TA, Zieman JC, Fourqurean JW, Madden CJ (2005) The potential role of plant oxygen and sulfide dynamics in die-off events of the tropical seagrass, Thalassia testudinum. J Ecol 93:148-158

Borum J, Sand-Jensen $\mathrm{K}$, Binzer $\mathrm{T}$, Pedersen $\mathrm{O}$, Greve $\mathrm{T}$ (2006) Oxygen movement in seagrasses. In: Larkum AWD, Orth RJ, Duarte CM (eds) Seagrasses: biology, ecology and conservation. Springer, Dordrecht, p 225-270

> Burke MK, Dennison WC, Moore KA (1996) Non-structural carbohydrate reserves of eelgrass Zostera marina. Mar Ecol Prog Ser 137:195-201

Carlson PR Jr, Yarbro LA, Barber TR (1994) Relationship of sediment sulfide to mortality of Thalassia testudinum in Florida Bay. Bull Mar Sci 54:733-746

$>$ Cerco CF, Moore KA (2001) System-wide submerged aquatic vegetation model for Chesapeake Bay. Estuaries 24:522-534

Chen SN, Sanford LP, Koch EW, Shi F, North EW (2007) A nearshore model to investigate the effects of seagrass bed geometry on wave attenuation and suspended sediment transport. Estuar Coasts 30:296-310

> Clemente-Colon P, Yan XH (1999) Observations of east coast upwelling conditions in synthetic aperture radar imagery. IEEE Trans Geosci Rem Sens 37:2239-2248

> Crawford RMM, Braendle R (1996) Oxygen deprivation stress in a changing environment. J Exp Bot 47:145-159

> Dennison WC, Alberte RS (1982) Photosynthetic responses of Zostera marina L. (eelgrass) to in situ manipulations of light intensity. Oecologia 55:137-144

> Dennison WC, Alberte RS (1985) Role of daily light period in the depth distribution of Zostera marina (eelgrass). Mar Ecol Prog Ser 25:51-61

- Erskine JM, Koch MS (2000) Sulfide effects on Thalassia testudinum carbon balance and adenylate energy charge. Aquat Bot 67:275-285

Evans AS, Webb KL, Penhale PA (1986) Photosynthetic temperature acclimation in two coexisting seagrasses, Zostera marina L. and Ruppia maritima L. Aquat Bot 24:185-197

Frederiksen MS, Holmer M, Borum J, Kennedy H (2006) Temporal and spatial variation of sulfide invasion in eelgrass (Zostera marina) as reflected by its sulfur isotopic composition. Limnol Oceanogr 51:2308-2318

> Gallegos CL (1994) Refining habitat requirements of submersed aquatic vegetation: role of optical models. Estuaries 17:187-199

Gallegos CL (2001) Calculating optical water quality targets to restore and protect submersed aquatic vegetation: overcoming problems in partitioning the diffuse attenuation coefficient for photosynthetically active radiation. Estuaries 24:381-397

Gallegos CL (2005) Optical water quality of a blackwater river estuary: the Lower St. Johns River, Florida, USA.
Estuar Coast Shelf Sci 63:57-72

> Gallegos CL, Correll DL, Pierce JW (1990) Modeling spectral diffuse attenuation, absorption, and scattering coefficients in a turbid estuary. Limnol Oceanogr 35:1486-1502

> Glenn SM, Crowley MF, Haidvogel DB, Song YT (1996) Underwater observatory capture coastal upwelling events off New jersey. EOS Trans Am Geophys Union 77: 233-236

> Golden RR, Busch KE, Karrh LP, Parham TA, Lewandowski MJ, Naylor MD (2010) Large-scale Zostera marina (eelgrass) restoration in Chesapeake Bay, Maryland, USA. Part II: a comparison of restoration methods in the Patuxent and Potomac Rivers. Restor Ecol 18:501-513

> Goodman JL, Moore KA, Dennison WC (1995) Photosynthetic responses of eelgrass (Zostera marina L.) to light and sediment sulfide in a shallow barrier island lagoon. Aquat Bot 50:37-47

Green EP, Short FT (2003) World atlas of seagrasses. University of California Press, Berkeley, CA

> Greve TM, Borum J, Pedersen O (2003) Meristematic oxygen variability in eelgrass (Zostera marina). Limnol Oceanogr 48:210-216

> Greve TM, Krause-Jensen D, Rasmussen MB, Christensen PB (2005) Means of rapid eelgrass (Zostera marina L.) recolonisation in former dieback areas. Aquat Bot 82: 143-156

> Hansen JCR, Reidenbach MA (2012) Wave and tidally driven flows in eelgrass beds and their effect on sediment suspension. Mar Ecol Prog Ser 448:271-287

> Holmer M, Bondgaard EJ (2001) Photosynthetic and growth response of eelgrass to low oxygen and high sulfide concentrations during hypoxic events. Aquat Bot 70:29-38

> Jarvis JC, Moore KA (2010) The role of seedlings and seed bank viability in the recovery of Chesapeake Bay, USA, Zostera marina populations following a large-scale decline. Hydrobiologia 649:55-68

> Kemp WM, Batiuk R, Bartleson R, Bergstrom P and others (2004) Habitat requirements for submerged aquatic vegetation in Chesapeake Bay: water quality, light regime, and physical-chemical factors. Estuaries 27:363-377

Koch MS, Erskine JM (2001) Sulfide as a phytotoxin to the tropical seagrass Thalassia testudinum: interactions with light, salinity and temperature. J Exp Mar Biol Ecol 266: 81-95

Koch EW, Orth RJ (2003) Seagrasses of the mid-Atlantic coast of the United States. In: Green EP, Short FT (eds) World atlas of seagrasses. University of California Press, Berkeley, CA, p 216-223

Koch EW, Ackerman J, van Keulen M, Verduin J (2006) Fluid dynamics in seagrass ecology: from molecules to ecosystems. In: Larkum AWD, Orth RJ, Duarte CM (eds) Seagrasses: biology, ecology and conservation. Springer, Dordrecht, p 193-225

Koch MS, Schopmeyer SA, Holmer M, Madden CJ, KyhnHansen C (2007) Thalassia testudinum response to the interactive stressors hypersalinity, sulfide and hypoxia. Aquat Bot 87:104-110

Lawson SE, Wiberg PL, McGlathery KJ, Fugate DC (2007) Wind-driven sediment suspension controls light availability in a shallow coastal lagoon. Estuar Coasts 30:102-112

> Lee KS, Park SR, Kim YK (2007) Effects of irradiance, temperature and nutrients on growth dynamics of seagrasses: a review. J Exp Mar Biol Ecol 350:144-175

McGlathery KJ, Reynolds LK, Cole LW, Orth RJ, Marion SR, Schwarzschild A (2012) Recovery trajectories during state 
change from bare sediment to eelgrass dominance. Mar Ecol Prog Ser 448:209-221

Moore KA (2004) Influence of seagrasses on water quality in shallow regions of the lower Chesapeake Bay. J Coast Res 45(Spec Issue):162-178

Moore KA, Jarvis JC (2008) Environmental factors affecting recent summertime eelgrass diebacks in the lower Chesapeake Bay: implications for long-term persistence. J Coast Res 55(Spec Issue):135-147

Moore KA, Short FT (2006) Comparative biology of Zostera. In: Larkum AWD, Orth RJ, Duarte CM (eds) Seagrasses: biology, ecology and conservation. Springer, Dordrecht, p 361-386

Moore KA, Neckles HA, Orth RJ (1996) Zostera marina (eelgrass) growth and survival along a gradient of nutrients and turbidity in the lower Chesapeake Bay. Mar Ecol Prog Ser 142:247-259

Moore KA, Wetzel RL, Orth RJ (1997) Seasonal pulses of turbidity and their relations to eelgrass (Zostera marina L.) survival in an estuary. J Exp Mar Biol Ecol 215:115-134

Moore KA, Wilcox DJ, Orth RJ (2000) Analysis of the abundance of submersed aquatic vegetation communities in the Chesapeake Bay. Estuaries 23:115-127

Moore KA, Orth RJ, Wilcox DJ (2009) Assessment of the abundance of submersed aquatic vegetation (SAV) communities in the Chesapeake Bay and its use in SAV management. In: Yang X (ed) Remote sensing and geospatial technologies for coastal ecosystems assessment and management. Lecture Notes in Geoinformation and Cartography. Springer-Verlag, Berlin, p 233-357

Murray L, Wetzel RL (1987) Oxygen production and consumption associated with the major autotrophic components in two temperate seagrass communities. Mar Ecol Prog Ser 38:231-239

Orth RJ, Moore KA (1984) Distribution of abundance of submerged aquatic vegetation in Chesapeake Bay: an historical perspective. Estuaries 7:531-540

> Orth RJ, Moore KA (1986) Seasonal and year-to-year variations in the growth of Zostera marina L. (eelgrass) in the Chesapeake Bay. Aquat Bot 24:335-341

> Orth RJ, Carruthers TJB, Dennison WC, Duarte CM and others (2006a) A global crisis for seagrass ecosystems. Bioscience 56:987-996

Orth RJ, Luckenbach ML, Marion SR, Moore KA, Wilcox DJ (2006b) Seagrass recovery in the Delmarva Coastal Bays, USA. Aquat Bot 84:26-36

Orth RJ, Marion SR, Moore KA, Wilcox DJ (2010a) Eelgrass (Zostera marina L.) in the Chesapeake Bay region of midAtlantic coast of the USA: challenges in conservation and restoration. Estuar Coasts 33:139-150

Orth RJ, Williams MR, Marion SR, Wilcox DJ and others (2010b) Long term trends in submersed aquatic vegetation (SAV) in Chesapeake Bay, USA, related to water quality. Estuar Coasts 33:1144-1163

Submitted: July 4, 2011; Accepted: December 28, 2011
Orth RJ, Wilcox DJ, Whiting JR, Nagey LS, Owens AL, Kenne AK (2010c) Distribution of submerged aquatic vegetation in Chesapeake Bay and coastal bays - 2009. VIMS Special Scientific Report No. 152. Final report to US EPA Chesapeake Bay Program, Annapolis, MD

Orth RJ, Moore KA, Marion SR, Wilcox DJ, Parrish DB (2012) Seed addition facilitates eelgrass recovery in a coastal bay system. Mar Ecol Prog Ser 448:177-195

> Pastres R, Brigolin D, Petrizzo A, Zucchetta M (2004) Testing the robustness of primary production models in shallow coastal areas: a case study. Ecol Model 179:221-233

> Pulido C, Borum J (2010) Eelgrass (Zostera marina) tolerance to anoxia. J Exp Mar Biol Ecol 385:8-13

Rasmussen E (1977) The wasting disease of eelgrass (Zostera marina) and its effects on environmental factors and fauna. In McRoy CP, Helfferich C (eds) Seagrass ecosystems. Marcel Dekker, New York, NY, p 1-51

Robblee MB, Barber TR, Carlson PR Jr, Durako MJ and others (1991) Mass mortality of the tropical seagrass Thalassia testudinum in Florida Bay (USA). Mar Ecol Prog Ser 71:297-299

> Short FT, Neckles HA (1999) The effects of global climate change on seagrasses. Aquat Bot 63:169-196

Short FT, Polidoro B, Livingstone SR, Carpenter KE and others (2011) Extinction risk assessment of the world's seagrass species. Biol Conserv 144:1961-1971

Siegel S, Castellan NJ (1988) Nonparametric statistics for the behavioral sciences (2nd edn). McGraw-Hill, New York, NY

> Staehr PR, Borum J (2011) Seasonal acclimation in metabolism reduces light requirements of eelgrass (Zostera marina). J Exp Mar Biol Ecol 407:139-146

> Tanner C, Hunter S, Reel J, Parham T and others (2010) Evaluating a large-scale eelgrass restoration project in the Chesapeake Bay. Restor Ecol 18:538-548

Vartapetian BB, Jackson MB (1997) Plant adaptations to anaerobic stress. Ann Bot (Lond) 79(Suppl 1):3-20

- Waycott M, Duarte CM, Carruthers TJB, Orth RJ and others (2009) Accelerating loss of seagrasses across the globe threatens coastal ecosystems. Proc Natl Acad Sci USA 106:12377-12381

Wetzel RL, Penhale PA (1983) Production ecology of seagrass communities in the lower Chesapeake Bay. Mar Technol Soc J 17:22-31

Zharova N, Sfriso A, Voinov A, Pavoni B (2001) A simulation model for the annual fluctuation of Zostera marina biomass in the Venice lagoon. Aquat Bot 70:135-150

> Zimmerman RC, Smith RD, Alberte RS (1989) Thermal acclimation and whole-plant carbon balance in Zostera marina L. (eelgrass). J Exp Mar Biol Ecol 130:93-109

Zimmerman RC, Cabello-Pasini A, Alberte RS (1994) Modeling daily production of aquatic macrophytes from irradiance measurements: a comparative analysis. Mar Ecol Prog Ser 114:185-196

Proofs received from author(s): February 8, 2012 